\title{
Effects of gentaminoseleferon on blood parameters during treatment of Mycoplasma dispar respiratory infection in calves
}

\author{
Mohammad Abed Alhussen ${ }^{(\mathbb{D}}$, Hamdan Naef ${ }^{\mathbb{D}}$ and Yury Anatolyevich Vatnikov ${ }^{(\mathbb{D}}$ \\ Department of Veterinary Medicine, Peoples' Friendship University of Russia (RUDN University), 6 Miklukho-Maklaya \\ Street, Moscow 117198, Russian Federation. \\ Corresponding author: Mohammad Abed Alhussen, e-mail: alhussenmohammed85@hotmail.com \\ Co-authors: HN: dhamdan123@hotmail.com, YAV: vatnikov@yandex.ru \\ Received: 27-05-2020, Accepted: 11-09-2020, Published online: 21-10-2020
}

doi: www.doi.org/10.14202/vetworld.2020.2197-2202 How to cite this article: Abed Alhussen M, Naef H, Vatnikov YA (2020) Effects of gentaminoseleferon on blood parameters during treatment of Mycoplasma dispar respiratory infection in calves, Veterinary World, 13(10): 2197-2202.

\begin{abstract}
Background and Aim: Respiratory diseases in young cattle are among the significant cattle pathologies that cause considerable economic damage globally. For the treatment of respiratory diseases, coformulated drugs that increase general nonspecific resistance, exhibit adaptogenic and anti-inflammatory properties, and normalize metabolic processes in animals are currently being used. The aim of our study was to investigate the therapeutic efficacy of the complex drug "gentaminoseleferon", used in the treatment of respiratory diseases in calves, especially in Mycoplasma dispar infection.

Materials and Methods: The animals were divided into three groups. Calves with the first clinical signs of respiratory pathology were randomly divided into two groups. The first experimental group $(\mathrm{n}=5)$ was intramuscularly injected with sulfetrisan at a dose of 5-10 mL/animal once per day for 7 days. The second experimental group $(\mathrm{n}=5)$ was given gentaminoseleferon at a dose of $1 \mathrm{~mL} / 10 \mathrm{~kg}$ of body weight once per day for 7 days. The drugs were not used in the control group, the "healthy animals $(\mathrm{n}=5)$ ". Blood samples were taken 10 days before and after treatment and compared between the experimental and healthy calves. The changes in the hematological and biochemical parameters of blood and serum were evaluated.

Results: During the recovery process of animals in the experimental groups, a normalization of the hematological and biochemical parameters of blood and serum was noted. Interestingly, in calves of the second experimental group, an increase in the total serum protein content by $2.2 \%(\mathrm{p}<0.05)$ was recorded in comparison with the first group. The second group, furthermore, showed an increase in Vitamins A, E, and C concentrations by $13.5 \%(\mathrm{p}<0.05), 11.9 \%(\mathrm{p}<0.005)$, and $15.1 \%$ $(\mathrm{p}<0.0005)$, respectively, as well as in zinc and iron concentrations by $4.1 \%(\mathrm{p}<0.05)$ and $9.3 \%(\mathrm{p}<0.0001)$, respectively. These findings indicate a more pronounced decrease in the inflammatory process in the respiratory system and intensive restoration of metabolism, thereby establishing the high therapeutic efficacy of gentaminoseleferon.

Conclusion: Gentaminoseleferon was proven highly effective in the treatment of calves with respiratory illnesses and in restoring homeostasis in the organisms of animals after treatment, as indicated by the normalization of morphological and biochemical blood parameters with a reduction in the recovery time.
\end{abstract}

Keywords: blood parameters, calves, gentaminoseleferon, Mycoplasma dispar, respiratory diseases.

\section{Introduction}

Respiratory diseases in calves are among the most significant cattle pathologies in the world [1]. The morbidity in calves due to respiratory diseases is about $30-65 \%$ annually and causes a mortality rate of $10-31 \%$ [2-4]. In addition, respiratory diseases hamper the growth rate of young animals, growth retardation, and dysfunction of the reproductive organs, which in sum causes significant economic damage [5].

Mycoplasma dispar is one of the most important agents causing respiratory disease in cattle $[6,7]$ that are classified under genus Mycoplasma and

Copyright: Abed Alhussen, et al. Open Access. This article is distributed under the terms of the Creative Commons Attribution 4.0 International License (http://creativecommons.org/licenses/ by/4.0/), which permits unrestricted use, distribution, and reproduction in any medium, provided you give appropriate credit to the original author(s) and the source, provide a link to the Creative Commons license, and indicate if changes were made. The Creative Commons Public Domain Dedication waiver (http:// creativecommons.org/publicdomain/zero/1.0/) applies to the data made available in this article, unless otherwise stated. class Mollicutes. M. dispar has a small genome size of $803 \mathrm{kbp}$ [8], possesses no cell wall, and has a low guanine-cytosine ratio (28.5-29.3 mol\%) [9]. M. dispar causes mild pneumonia in calves and mastitis in adult cattle. It is usually isolated from lungs and nasal swabs of pulmonary and healthy calves. $M$. dispar is very sensitive to culture in vitro and requires a special media. It is considered one of the slowest growing types of mycoplasmas [10]. Many studies have indicated that $M$. dispar is present in $50 \%$ of examined flocks and has coexisted with other bacterial agents, such as Pasteurella multocida, Arcanobacterium pyogenes, and Mannheimia haemolytica [11]. M. dispar in calves appears to be less immunogenic, and the vaccine, which is given by intramuscular injection(inoculations were antigen mixed with Freund's complete or incomplete adjuvant), intra-tracheal(inoculations consisted of antigen in saline), or both, does not provide detectable protection against colonization, which can be at least partially pathogenic [12]. 
To increase immunity in young animals, it is recommended to use complex preparations as a form of treatment and prophylactic measures that contribute to the activation of metabolism, correction of immunity, and increase of nonspecific body resistance, among others [13-16].

One of such drug formulations is gentaminoseleferon, which contains gentamicin sulfate, aminoseleton, and a mixture of bovine recombinant $\alpha$ - and $\gamma$-interferon (INF) proteins. Gentamicin has a bactericidal effect against most Gram-positive and Gram-negative micro-organisms. The principle of action of gentamicin is its binding to the $30 \mathrm{~S}$ subunit of bacterial ribosomes, impairing protein synthesis, and preventing the formation of tRNA and mRNA complexes, which leads to the erroneous reading of RNA and the formation of non-functional proteins in bacterial cells [17]. Aminoseleton is obtained by cryofractionation using biotechnology and represents a hydrophilic fraction of bovine spleen tissue, which contains a complex of biologically active substances such as amino acids, peptides, and nucleic acids. Aminoseleton increases the nonspecific resistance of the body, accelerates metabolism, and exhibits adaptogenic and antioxidant properties [18-20]. Bovine recombinant INFs implement rapid induction of the endogenous cytokine system and cellular and humoral immunity and exert anti-inflammatory and anti-stress effects. $\alpha$-INF and $\gamma$-INF are synergistic, enhance the antibacterial effect of antibiotics, and reduce their possible suppressive effects $[21,22]$.

The aim of the present study was to elucidate the therapeutic efficacy of the complex preparation gentaminoseleferon (developed at the Federal State Budgetary Scientific Institution [FSBSI], All-Russian Scientific Research Veterinary Institute of Pathology, Pharmacology and Therapy) in the treatment of $M$. dispar respiratory infections in calves.

\section{Materials and Methods}

\section{Ethical approval}

The study was conducted in accordance with the State program of Peoples' Friendship University of Russia (RUDN University) after receiving approval from the Shared Research and Educational Center (SREC PFUR).

\section{Study location and period}

The study was conducted at the research laboratory of the Department of Human and Animal Physiology at the Voronezh State University and the Department of Experimental Therapy in the AllRussian Scientific Research Veterinary Institute of Pathology, Pharmacology and Therapy, in the year 2019 (from 20 May to 11 August). The clinical studies were carried out on 3-5-month old red-mottled breed calves in a farm operated by Voronezhpishcheproduct Ltd., Novaya Usman, Voronezh Region.

\section{Animals and experimental design}

Fifteen calves weighing from 75 to $88 \mathrm{~kg}$ were selected and divided into three groups. Calves with the first clinical signs of respiratory illness were randomly divided into two experimental groups $(\mathrm{n}=5$ each). The calves in the first experimental group $(n=5)$ were subjected to the treatment program adopted on the farm using sulfetrisan administered intramuscularly at $5-10 \mathrm{~mL}$ per animal once per day for 7 days. Meanwhile, the calves in the second experimental group $(n=5)$ were intramuscularly injected with a new preparation, gentaminoseleferon, at $1 \mathrm{~mL} / 10 \mathrm{~kg}$ of body weight, once per day for 7 days. This dosage was determined based on the previous pharmacological and clinical research conducted at the institute. Healthy calves $(n=5)$ comprised the third group as the control and were not given any treatments.

\section{Clinical, bacteriological and molecular genetic examinations}

The diagnosis was performed comprehensively based on the results of clinical and laboratory studies. We took into account the general indicators of health, such as body temperature, food intake, behavior, and habitus. The respiratory system was assessed by visual inspection (respiratory rate, nasal discharge, type of breathing, shortness of breath, dry, or wet spontaneous cough) and auscultation (increased or decreased volume of breathing sounds, rales, and signs of breathing difficulty). Materials collected for this study were blood, serum, and nasal cavity swabs. Bacteriological studies were carried out by culturing the pathogens on appropriate media using generally accepted methods at the FSBSI Research Center, All-Russian Scientific Research Veterinary Institute of Pathology, Pharmacology and Therapy. Molecular genetic studies of the biological materials were conducted through the real-time polymerase chain reaction (qPCR) using own commercial kits for M. dispar, infectious bovine rhinotracheitis virus, bovine viral diarrhea virus, and parainfluenza virus-3 detection in accordance with their instructions for use.

\section{Blood tests}

To conduct hematological and biochemical studies, the blood samples were taken from both healthy and infected calves (experimental groups) 10 days before and after treatment. Hematological analysis was carried out on a ABX Micros 60 hematology analyzer using standard methods. Biochemical tests on blood serum were performed on a Hitachi-902 analyzer. During the experiment, the calves were monitored, the general health condition of the animals and weight gain were evaluated, the number of recovered animals and the duration of treatment and the timing of recovery were taken into account.

\section{Statistical analysis}

A comparative assessment of the average values of the measurements was carried out using analysis of variance using the statistical program StatPlus version 5(AnalystSoft - USA)

\section{Results and Discussion}

Respiratory diseases in young cattle cause inflammation that negatively impact the average daily 
weight gain and growth-to-feed ratio $[23,24]$. The cytokines released as a result of inflammation induce clinical symptoms, including fever, a sharp decrease in appetite, and, consequently, weight loss. Changes in some metabolic processes are also brought about, such as increased white blood cell count, decreased zinc, iron, vitamin, and other microelement serum concentrations [24-26]. A widespread prevalence of cattle mycoplasma in farms in the Russian Federation has been reported [27,28] where it is considered one of the most important agents in respiratory system illnesses in calves. Table-1 shows the spread of $M$. dispar in the Russian Federation in the years 2015-2018 [27].

Bacteriological examination of nasal swabs collected from infected calves isolated Staphylococcus aureus, Staphylococcus epidermidis, M. dispar, and $P$. multocida, which are sensitive to gentamicin, tylosin, neomycin, norfloxacin, enrofloxacin, amoxicillin, ampicillin, doxycycline, and tetracycline. Molecular genetic analysis isolated the $M$. dispar genome, whereas genomes of the infectious bovine rhinotracheitis virus, bovine viral diarrhea virus, and parainfluenza virus-3 were not found.

The results of some hematological and biochemical parameters in calves during treatment with sulfetrisan are presented in Tables- 2 and 3.

In sick calves of the first experimental group, the white blood cell count increased by $36.8 \%$ ( $<<0.001$, indicating an inflammation), hemoglobin concentration decreased by $13.9 \%(\mathrm{p}<0.0005)$, and the red blood

Table-1: The prevalence of Mycoplasma dispar in the Russian Federation between 2015 and 2018.

\begin{tabular}{lcccc}
\hline Year & $\mathbf{2 0 1 5}$ & $\mathbf{2 0 1 6}$ & $\mathbf{2 0 1 7}$ & $\mathbf{2 0 1 8}$ \\
\hline Mycoplasma dispar (\%) & 22.1 & 27.2 & 53.2 & 46.1 \\
\hline
\end{tabular}

cell count increased by $15.1 \%(p<0.005)$, apparently as a compensatory reaction due to hypoxemia, which may, in turn, lead to polycythemia [29]). Treatment with sulfetrisan increased hemoglobin concentration by $11.0 \%(p<0.001)$ and decreased the white blood cell count by $21.7 \%(p<0.005)$. When compared with healthy animals, these hematological parameters indicate an incomplete body recovery after infection.

In sick calves of the first experimental group, serum concentrations of Vitamins $\mathrm{A}, \mathrm{E}$, and $\mathrm{C}$ decreased by $31.1 \%(p<0.005), 26.7 \%(p<0.0005)$, and $24.7 \% \quad(p<0.0005)$, respectively, whereas the serum concentrations of magnesium, zinc, iron, and copper decreased by $6 \%(\mathrm{p}<0.0005), 10.3 \%$ $(p<0.0005), 19.7 \%(p<0.0001)$, and 2.7\% $(p<0.05)$, respectively. Furthermore, the total protein level in serum decreased by $8.2 \%(p<0.001)$, which indicates a decrease in energy processes and insufficiency of protein-mineral metabolism against the background of the inflammatory process. This seems to occur as a result of the anorexia and, thus, the lack of intake of the necessary minerals and vitamins, the blood serum concentrations of which depend mainly on dietary intake [30]. Moreover, the decrease in the serum concentrations of vitamins and microelements is due to increase demand to repair the damage caused by acute or chronic inflammation [31]. After treatment with sulfetrisan, calves showed an increase in concentrations of Vitamin A by $21.9 \%(p<0.002)$, Vitamin C by $18.9 \%(p<0.002)$, and Vitamin E by $21.1 \%$ $(p<0.0005)$. Blood serum concentrations of zinc, iron, and total protein also increased by $5.4 \%(\mathrm{p}<0.005)$, $13.8 \%(\mathrm{p}<0.0005)$, and $7.9 \%(\mathrm{p}<0.002)$, respectively.

However, compared with those of healthy animals, Vitamins $\mathrm{A}, \mathrm{E}$, and $\mathrm{C}$ concentrations were lower by $16 \%(p<0.05), 11.3 \%(p<0.005)$, and $10.5 \%$

Table-2: Changes in some hematological parameters in calves during treatment with sulfetrisan (mean $\pm S D$ ).

\begin{tabular}{|c|c|c|c|}
\hline \multirow[t]{2}{*}{ Parameter } & \multirow[t]{2}{*}{ Healthy calves } & \multicolumn{2}{|c|}{ Infected calves } \\
\hline & & Before treatment & After treatment \\
\hline $\mathrm{RBC}\left(10^{12} / \mathrm{L}\right)$ & $7.22 \pm 0.144$ & $8.31 \pm 0.199 * *$ & $7.85 \pm 0.268 *$ \\
\hline WBC $\left(10^{9} / \mathrm{L}\right)$ & $7.50 \pm 0.288$ & $10.26 \pm 0.457 * *$ & $8.03 \pm 0.410^{* *}$ \\
\hline $\mathrm{Hb}(\mathrm{g} / \mathrm{L})$ & $113.25 \pm 1.943$ & $97.50 \pm 1.936 * * *$ & $108.25 \pm 0.559 * *$ \\
\hline
\end{tabular}

$\mathrm{Hb}=$ Hemoglobin, $\mathrm{RBC}=$ Red blood cell, $\mathrm{WBC}=$ White blood cell. $* \mathrm{p}<0.02-0.05 ; * * \mathrm{p}<0.001-0.005 ; * * * \mathrm{p}<0.0002-0.0005$ in relation to the parameters of healthy calves; ${ }^{p}<0.05 ; " * p<0.001-0.005$ in relation to parameters before treatment

Table-3: Changes in some biochemical parameters in blood serum of calves during treatment with sulfetrisan (mean \pm SD).

\begin{tabular}{|c|c|c|c|}
\hline \multirow[t]{2}{*}{ Parameter } & \multirow[t]{2}{*}{ Healthy calves } & \multicolumn{2}{|c|}{ Infected calves } \\
\hline & & Before treatment & After treatment \\
\hline Vitamin A $(\mu \mathrm{mol} / \mathrm{L})$ & $1.06 \pm 0.093$ & $0.73 \pm 0.038 * *$ & $0.89 \pm 0.025^{* \bullet *}$ \\
\hline Vitamin E ( $\mu \mathrm{mol} / \mathrm{L})$ & $9.72 \pm 0.387$ & $7.12 \pm 0.254 * * *$ & $8.62 \pm 0.097 * * \cdots$ \\
\hline Vitamin C ( $\mu \mathrm{mol} / \mathrm{L})$ & $28.30 \pm 1.122$ & $21.32 \pm 0.968 * * *$ & $25.34 \pm 0.650 * *$ \\
\hline Total protein $(\mathrm{g} / \mathrm{L})$ & $70.28 \pm 0.510$ & $64.5 \pm 0.962 * *$ & $69.58 \pm 0.459 * *$ \\
\hline Magnesium (mmol/L) & $0.84 \pm 0.004$ & $0.79 \pm 0.01 * * *$ & $0.81 \pm 0.007 * * *$ \\
\hline Zinc $(\mu \mathrm{g} / \mathrm{dL})$ & $114.20 \pm 2.563$ & $102.39 \pm 1.163 * * *$ & $107.88 \pm 1.773^{* *}$ \\
\hline Iron $(\mu \mathrm{g} / \mathrm{dL})$ & $195.66 \pm 0.937$ & $157.20 \pm 3.549 * * *$ & $178.97 \pm 1.026 * * * * *$ \\
\hline Copper $(\mu \mathrm{g} / \mathrm{dL})$ & $138.94 \pm 1.522$ & $135.22 \pm 1.322 *$ & $136.64 \pm 1.123$ \\
\hline
\end{tabular}


$(p<0.05)$, respectively, whereas blood serum magnesium, zinc, and iron concentrations in blood serum were lower by $3.6 \%(\mathrm{p}<0.0005), 5.5 \%(\mathrm{p}<0.05)$, and $8.5 \%(\mathrm{p}<0.0001)$, respectively, indicating incomplete recovery after disease.

The results of some hematological and biochemical parameters in calves during treatment with gentaminoseleferon are presented in Tables-4 and 5.

The inflammatory process in calves of the second experimental group was indicated by a decrease in hemoglobin concentration by $15.3 \%(p<0.002)$, an increase in the red blood cell count by $17.7 \%$ $(\mathrm{p}<0.002)$, and an increase in the white blood cell count by $44.0 \%(p<0.0005)$. After treatment with gentaminoseleferon, hemoglobin levels increased by $14.6 \%(p<0.005)$, the red blood cell count decreased by $10.5 \% \quad(\mathrm{p}<0.05)$, and white blood cell count decreased by $28.6 \%(p<0.001)$.

In the calves from the second group, Vitamins $\mathrm{A}, \mathrm{E}$, and $\mathrm{C}$ concentrations in blood serum decreased by $32.1 \%(p<0.005), 24.5 \%(p<0.0005)$, and $24.2 \%$ $(\mathrm{p}<0.0001)$, respectively, whereas magnesium, zinc, iron, and copper concentrations decreased by $6 \%$ $(p<0.0001), 10.4 \%(p<0.0005), 20.2 \% \quad(p<0.0001)$, and $2.9 \%(p<0.05)$, respectively. Furthermore, the total protein level decreased by $9.6 \%(p<0.0001)$, which indicated insufficient metabolic activity during the respiratory infection.

During recovery after treatment with gentaminoseleferon, Vitamins A, C, and E concentrations increased by $40.3 \%(p<0.0005), 36 \%(p<0.0001)$, and $31.5 \%(\mathrm{p}<0.0001)$, respectively, whereas zinc, iron, and total protein concentrations increased by 9.7\% $(p<0.0005), 25.3 \%(p<0.0001)$, and $11.9 \%$ $(\mathrm{p}<0.0005)$, respectively. This indicated a decline in the inflammatory process and normalization of metabolism.

It should be noted that the use of gentaminoseleferon, as compared with sulfetrisan, contributed to an increase in the total protein content by $2.2 \%(p<0.05)$, and in Vitamins A, E, and C concentrations by $13.5 \%$ $(p<0.05), 11.9 \%(p<0.005)$, and $15.1 \%(p<0.0005)$, respectively. Furthermore, serum concentrations of zinc and iron increased by $4.1 \%(\mathrm{p}<0.05)$ and $9.3 \%$

Table-4: Changes in some hematological parameters in calves during treatment with gentaminoseleferon (mean \pm SD).

\begin{tabular}{lccc}
\hline Parameter & Healthy calves & \multicolumn{2}{c}{ Infected calves } \\
\cline { 3 - 4 } & & Before treatment & After treatment \\
\hline RBC $\left(10^{12} / \mathrm{L}\right)$ & $7.22 \pm 0.144$ & $8.50 \pm 0.229 * *$ & $7.60 \pm 0.316^{*}$ \\
WBC $\left(10^{9} / \mathrm{L}\right)$ & $7.50 \pm 0.288$ & $10.80 \pm 0.505^{* * *}$ & $7.71 \pm 0.311^{* *}$ \\
$\mathrm{Hb}(\mathrm{g} / \mathrm{L})$ & $113.25 \pm 1.943$ & $95.88 \pm 3.461^{* *}$ & $109.88 \pm 0.944^{* *}$ \\
\hline
\end{tabular}

$\mathrm{Hb}=$ Hemoglobin, $\mathrm{RBC}=$ Red blood cell, $\mathrm{WBC}=$ White blood cell. $* \mathrm{p}<0.02-0.05 ; * * \mathrm{p}<0.002 ; * * * \mathrm{p}<0.0001-0.0005$ in relation to the parameters of healthy calves; $" p<0.05 ; " * p<0.001-0.005$ in relation to parameters before treatment

Table-5: Changes in some biochemical parameters in blood serum of calves during treatment with gentaminoseleferon (mean \pm SD).

\begin{tabular}{|c|c|c|c|}
\hline \multirow[t]{2}{*}{ Parameter } & \multirow[t]{2}{*}{ Healthy calves } & \multicolumn{2}{|c|}{ Infected calves } \\
\hline & & Before treatment & After treatment \\
\hline Vitamin A $(\mu \mathrm{mol} / \mathrm{L})$ & $1.06 \pm 0.093$ & $0.72 \pm 0.04 * *$ & $1.01 \pm 0.059 \%$ \\
\hline Vitamin $E(\mu \mathrm{mol} / \mathrm{L})$ & $9.72 \pm 0.387$ & $7.34 \pm 0.266 * * *$ & $9.65 \pm 0.359 \cdots$ \\
\hline Vitamin C $(\mu \mathrm{mol} / \mathrm{L})$ & $28.30 \pm 1.122$ & $21.44 \pm 0.535^{* * *}$ & $29.16 \pm 0.5^{\cdots *}$ \\
\hline Total protein $(\mathrm{g} / \mathrm{L})$ & $70.28 \pm 0.510$ & $63.52 \pm 0.734 * * *$ & $71.10 \pm 0.503^{* * *}$ \\
\hline Magnesium (mmol/L) & $0.84 \pm 0.004$ & $0.79 \pm 0.009 * * *$ & $0.82 \pm 0.07$ \\
\hline Zinc $(\mu \mathrm{g} / \mathrm{dL})$ & $114.20 \pm 2.563$ & $102.30 \pm 1.479 * * *$ & $112.26 \pm 1.674^{* * *}$ \\
\hline Iron $(\mu \mathrm{g} / \mathrm{dL})$ & $195.66 \pm 0.937$ & $156.15 \pm 5.617 * * *$ & $195.61 \pm 0.928^{* * *}$ \\
\hline Copper $(\mu \mathrm{g} / \mathrm{dL})$ & $138.94 \pm 1.522$ & $134.96 \pm 0.690 *$ & $137.40 \pm 1.352$ \\
\hline
\end{tabular}

Table-6: Therapeutic efficacy of sulfetrisan and gentaminoseleferon in treatment of respiratory diseases of calves.

\begin{tabular}{lcc}
\hline Indicator & Sulfetrisan & Gentaminoseleferon \\
\hline The number of animals in the group (animal) & 5 & 5 \\
Duration of treatment (days) & 7 & 7 \\
Number of recovered animals (\%) & $4(80)$ & $5(100)$ \\
Number of dead animals (\%) & $0(0)$ & $0(0)$ \\
Remained sick animals (\%) & $1(20)$ & $0(0)$ \\
Calves weight at the beginning of the experiment (kg) & $83.50 \pm 0.866$ & $84.88 \pm 1.025$ \\
Calves weight at the end of the experiment (kg) & $88.86 \pm 0.996$ & $91.55 \pm 0.944^{*}$ \\
Average of daily gain (g) & $412 \pm 10.2$ & $513 \pm 22.7 *$ \\
Recovery duration (days) & $14.13 \pm 0.854$ & $10.88 \pm 0.398^{*}$ \\
Therapeutic efficacy \% & 80.0 & 100.0 \\
\hline
\end{tabular}

$*_{p}<0.01-0.002$ in relation to indicators of calves treated with sulfetrisan. 
$(p<0.0001)$, respectively. The improvements in these parameters indicated a more pronounced decrease in the inflammatory process and intensive restoration of protein-energy metabolism in calves in the second experimental group. The ability of components of gentaminoseleferon to influence the indicators of nonspecific resistance is confirmed by previous studies $[18,22]$.

The results of the therapeutic efficacy of sulfetrisan and gentaminoseleferon in the treatment of respiratory diseases in calves are presented in Table- 6 .

Based on the data gathered, gentaminoseleferon showed high therapeutic efficacy $(100 \%)$ in the treatment of respiratory diseases in calves and $0.20 \%$ higher than the comparison drug. At the same time, the recovery time was $23.3 \%(\mathrm{p}<0.01)$ shorter and the average daily weight gain upon recovery was $24.5 \%$ $(\mathrm{p}<0.002)$ higher.

\section{Conclusion}

Our results show that, due to its components, gentaminoseleferon exhibits high therapeutic efficacy in the treatment of calves with respiratory diseases and helps reduce their recovery time. The drug provides an intensive restoration of protein-energy metabolism and a pronounced decrease in the inflammatory process, as proved by the normalization of morphological and biochemical blood parameters. Moreover, the drug has the ability to improve the general metabolism processes in calves, represented by improved levels of vitamins and microelements in the blood serum. Further studies of the mechanism of action of the drug on a large scale, as well as its introduction into calf breeding technology, are a promising direction for pharmacocorrection of respiratory pathologies.

\section{Authors' Contributions}

MAA and HN carried out the experiments, analyzed and interpreted of data, and drafted the manuscript. YAV supervised the project, and revised the manuscript. All authors have checked and approved the final version of the manuscript.

\section{Acknowledgments}

This paper was financially supported by the Ministry of Education and Science of the Russian Federation on the program to improve the competitiveness of Peoples' Friendship University of Russia (RUDN University) among the world's leading research and education centers in 2016-2020. The publication was prepared with the support of the "RUDN University Program 5-100" (the agreement number 02.a03.0008). The authors would like to thank for the support received from their respective institutes and universities that participated in this study.

\section{Competing Interests}

The authors declare that they have no competing interests.

\section{Publisher's Note}

Veterinary World remains neutral with regard to jurisdictional claims in published institutional affiliation.

\section{References}

1. Murray, G.M., More, S.J., Clegg, T.A., Earley, B., O’Neill, R.G., Johnston, D., Gilmore, J., Nosov, M., McElroy, M.C., Inzana, T.J. and Cassidy, J.P. (2018) Risk factors associated with exposure to bovine respiratory disease pathogens during the peri-weaning period in dairy bull calves. BMC Vet. Res., 14(1): 53.

2. Constable, P., Hinchcliff, K.W., Done, S. and Gruenberg, W. (2016) Veterinary Medicine: A Textbook of the Diseases of Cattle, Horses, Sheep, Pigs and Goats Two-Volume Set. Saunders Ltd., England.

3. Taylor, J.D., Fulton, R.W., Lehenbauer, T.W., Step, D.L. and Confer, A.W. (2010) The epidemiology of bovine respiratory disease: What is the evidence for predisposing factors? Can. Vet. J., 51(10): 1095-1102.

4. Dubrovsky, S.A., Van Eenennaam, A.L., Karle, B.M., Rossitto, P.V., Lehenbauer, T.W. and Aly, S.S. (2019) Epidemiology of bovine respiratory disease (BRD) in preweaned calves on California dairies: The BRD 10K study. J. Dairy Sci., 102(8): 7306-7319.

5. Louie, A.P., Rowe, J.D., Love, W.J., Lehenbauer, T.W. and Aly, S.S. (2018) Effect of the environment on the risk of respiratory disease in preweaning dairy calves during summer months. J. Dairy Sci., 101(11): 10230-10247.

6. Mosier, D. (2014) Review of BRD pathogenesis: The old and the new. Anim. Health Res. Rev., 15(2): 166-168.

7. Tortorelli, G., Gaeta, N.C., Ribeiro, B.L.M., Marques, L.M., Timenetsky, J. and Gregory, L. (2017) Evaluation of Mollicutes microorganisms in respiratory disease of cattle and their relationship to clinical signs. J. Vet. Intern. Med., 31(4): 1215-1220.

8. Herrmann, R. (1992) Genome structure and organization. In: Mycoplasmas: Molecular Biology and Pathogenesis. American Society for Microbiology, Washington, DC. p157-168.

9. Nicholas, R., Ayling, R. and McAuliffe, L. (2008) Mycoplasma Diseases of Ruminants. Centre for Agriculture and Bioscience International, Wallingford,UK.

10. Chen, S., Hao, H., Yan, X., Liu, Y. and Chu, Y. (2019) Genome-wide analysis of Mycoplasma dispar provides insights into putative virulence factors and phylogenetic relationships. G3 (Bethesda), 9(2): 317-325.

11. Bednarek, D., Szymańska-Czerwińska, M. and Dudek, K. (2012) Bovine respiratory syndrome (BRD) etiopathogenesis, diagnosis and control. In: Perez-Marin, C.C., editor. A Bird's-Eye View of Veterinary Medicine. InTech, London. p363-378.

12. Barrett, D.C. (2000) The calf pneumonia complex-treatment decisions. Cattle Pract., 8(2): 135-138.

13. Abramov, V.E., Balyshev, A.V., Kashkovskaya, L.M. and Safarova, M.I. (2017) Lexoflon a new remedy for the treatment of calves with respiratory diseases. Vet. Med., (2): 11-15.

14. Polozyuk, O.N. (2018) Treatment of calf bronchopneumonia in conditions of livestock complexes. Bull. Don State Agrarian Univ., 4-1(30): 4-9.

15. Chernitskiy, A.E. and Shabunin, S.V. (2017) Prevention of respiratory diseases in the newborn calves with decreased viability. Vet. Med., (9): 10-16.

16. Pardon, B., Callens, J., Maris, J., Allais, L., Van Praet, W., Deprez, P. and Ribbens, S. (2020) Pathogen-specific risk factors in acute outbreaks of respiratory disease in calves. J. Dairy Sci., 103(3): 2556-2566.

17. Return Merchandise Authorization. (2012) The Register of Medicines of Russia. In: Aleksandrovskiy, Y.A., 
Vyshkovskiy, G.L. Encyclopedia of Medicines: Annual Collection. Vedanta, Moscow. p1612.

18. Shakhov, A.G., Shabunin, S.V., Vostroilova, G.A., Bliznetsova, G.N., Sashnina, L.Y. and Kantorovich, Y.A. (2017) Antioxidant status in albino rats vaccinated against salmonellosis under chronic action of T-2 toxin and its correction by aminoseleton. Russ. Agric. Sci. J., 43(6):512-515.

19. Savrasov, D.A., Parshin, P.A., Vatnikov, Y.A., Kulikov, E.V., Popova, I.A., Nikishov, A.A., Petrov, A.K., Petukhov, N.V. and Molchanova, M.A. (2019) Correction of the immune status of cows by using aminoseleton during the dry period for prevention of antenatal calf hypotrophy. J. Anim. Health Prod., 7(3): 99-105.

20. Miroshnichenko, A.G., Brukhanov, V.M., Gossen, I.Y. and Perfilyev, V.Y. (2016) Antioxidants capabilities in correction of gentamicin-induced nephrotoxicity in experimental infection. Kazan Med. J., 97(4): 572-578.

21. Altynbekov, O.M. and Andreeva, A.V. (2019) The effect of the drug bovine recombinant interferon and immunal on the accumulation of specific antibodies to causative agents of associative infections in the blood of calves. Bull. Bashkir State Agrarian Univ., 50(2): 45-49.

22. Zaitseva, A.V., Prokulevich, V.A., Dremach, G.E. and Zaitseva, V.V. (2019) The effect of bovine interferon in the composition of enrofloxavetferon-B on the content of specific proteins in the blood serum of calves. Viciebsk State Acad. Vet. Med., 55(1): 24-29.

23. Gardner, B.A., Dolezal, H.G., Bryant, L.K., Owens, F.N. and Smith, R.A. (1999) Health of finishing steers: Effects on performance, carcass traits, and meat tenderness. J. Anim. Sci., 77(12): 3168-3175.

24. Gifford, C.A., Holland, B.P., Mills, R.L., Maxwell, C.L., Farney, J.K., Terrill, S.J., Step, D.L., Richards, C.J., Burciaga Robles, L.O. and Krehbiel, C.R. (2012) Growth and development symposium: Impacts of inflammation on cattle growth and carcass merit. J. Anim. Sci., 90(5): 1438-1451.

25. Cray, C., Zaias, J. and Altman, N.H. (2009) Acute phase response in animals: A review. Comp. Med., 59(6): 517-526.

26. Gruys, E., Toussaint, M.J.M., Niewold, T.A. and Koopmans, S.J. (2005) Acute phase reaction and acutephase proteins. J. Zhejiang Univ. Sci., 6(11): 1045-1056.

27. Abed Alhussen M., Nesterov, A.A., Kirpichenko, V.V., Yatsentyuk, S.P., Sprygin, A.V., Byadovskaya, O.P. and Kononov, A.V. (2020) Bovine mycoplasmosis occurrence on livestock farms in the Russian Federation for 2015-2018. Vet. Sci. Today, 2(33): 102-108.

28. Sukhinin, A.A., Makavchik, S.A., Kuzmin, V.A., Fogel, L.S., Orekhov, D.A., Karpenko, L.Y. and Kan, F.L. (2017) Methodical Guidelines for Livestock and Poultry Mycoplasmoses Prevention and Eradication. State Academy of Veterinary Medicine, Saint Petersburg. p23.

29. Faez, F., Abdinasir, Y.O., Lawan, A., Zunita, Z., Rasedee, A., Mohd, Z.S. and Abdul, A.S. (2013) Haematological and biochemical alterations in calves following infection with Pasteurella multocida Type B: 2, bacterial lipopolysaccharide and outer membrane protein immunogens (OMP). Asian J. Anim. Vet. Adv., 8(6): 806-813.

30. Rowlands, G.J. (1980) A review of variations in the concentrations of metabolites in the blood of beef and dairy cattle associated with physiology, nutrition and disease, with particular reference to the interpretation of metabolic profiles. World Rev. Nutr. Diet., 35: 172-235.

31. Caram, L.M.O., Amaral, R.A.F., Ferrari, R., Tanni, S.E., Correa, C.R., Paiva, S.A.R. and Godoy, I. (2015) Serum Vitamin A and inflammatory markers in individuals with and without chronic obstructive pulmonary disease. Mediators Inflamm., 2015: 862086. 